\title{
TINDAK PIDANA PROSTITUSI BERKEDOK BISNIS PANTI PIJAT DI KOTA MAKASSAR
}

\author{
Andika Prawira Buana ${ }^{1}$, Hasnan $\mathrm{Hasbi}^{2}$, dan Muh. Fachri Said ${ }^{3}$ \\ ${ }^{123}$ Fakultas Hukum, Universitas Muslim Indonesia \\ andika.prawira@umi.ac.id
}

\begin{abstract}
ABSTRAK
Tindak pidana prostitusi diatur dalam Pasal 296 KUHP. Realitas yang ada di Kota Makassar masih banyaknya terdapat tempat-tempat prostitusi berkedok bisnis panti pijat. Hal ini tentu tidak sejalan dengan Pasal 296 KUHP, yang berarti ada suatu aturan hukum yang tidak efektif dikarenakan masih terjadinya pelanggaran atas aturan hukum tersebut. Oleh sebab itu masalah pokok pada penelitian ini adalah, "efektivitas KUHP terhadap tindak pidana prostitusi berkedok bisnis panti pijat di Kota Makassar". Penelitian ini adalah penelitian dengan tipe kualitatif dengan pendekatan yuridis empiris. Dengan tujuan untuk memperoleh gambaran tentang tindak pidana porstitusi berkedok bisnis panti pijat dalam perspektif KUHP di Kota Makassar. Hasil penelitian ini menjawab tidak efektifnya aturan KUHP terhadap tindak pidana tersebut disebabkan ada pihak yang sengaja menyediakan dan memudahkan izin usaha tempat prostitusi berkedok bisnis panti pijat, serta kebijakan pemerintah daerah menjadikan pajak bisnis ini sebagai Pendapatan Asli Daerah. Saran pemerintah pusat melakukan revisi KUHP untuk mengatur secara tegas terkait kejahatan prostitusi terselubung serta kebijakan pemerintah daerah terkait pungutan pajak bisnis tersebut perlu dikaji ulang dan meninjau langsung bisnis tersebut agar sesuai dengan izin usaha yang diberikan.
\end{abstract}

Kata Kunci : Tindak Pidana, Prostitusi, Panti Pijat, KUHP 


\section{PENDAHULUAN}

Demokrasi dan negara hukum adalah dua konsepsi mekanisme kekuasan dalam menjalankan roda pemerintahan negara. Kedua konsepsi tersebut saling berkaitan yang satu sama lainnya tidak dapat dipisahkan, karena pada satu sisi demokrasi memberikan landasan dan mekanisme kekuasaan berdasarkan prinsip persamaan dan kesederajatan manusia, pada sisi yang lain negara hukum memberikan patokan bahwa yang memerintah dalam suatu negara bukanlah manusia, tetapi hukum. ${ }^{1}$ Pernyataan bahwa Indonesia merupakan negara hukum juga mempunyai konsekuensi, bahwa Negara Indonesia menerapkan hukum sebagai tombak untuk menciptakan ketertiban, keamanan, keadilan serta kesejahteraan bagi warga negara, sehingga hukum itu bersifat mengikat bagi setiap tindakan yang dilakukan oleh warga negaranya.

Undang-Undang Dasar Negara Republik Indonesia Tahun 1945 (UUD NRI 1945) (amandemen) Pasal 1 ayat (3), "negara Indonesia adalah negara hukum". ${ }^{2}$ Sebagai Negara hukum harus memenuhi beberapa unsur antara lain pemerintah dalam melaksanakan (imperatif) tugas dan kewajibannya, harus berdasar hukum atau peraturan perundangundangan, adanya jaminan terhadap hak asasi manusia, adanya pembagian kekuasaan dalam negara, adanya pengawasan dari badanbadan peradilan.Mencermati pembahasan diatas, norma-norma sosial dalam Negara hukum jelas mengharamkan prostitusi, dan juga sudah ada Undang-Undang mengenai praktek prostitusi yang ditinjau dari segi Yuridis di dalam Kitab Undang-Undang Hukum Pidana (KUHP) yaitu

Muntoha, Demokrasi dan Negara Hukum, dalam Jurnal Hukum lus Quia lustum Vol.16 No.3 Juli, 2009, hlm.379

2 Dayanto, "Rekonstruksi Paradigma Pembagunan Negara Hukum Indonesia Berbasis Pancasila", Jurnal Dinamika Hukum, Vol. 13, No. 3, September 2013,Purwokerto: Fakultas Hukum, Universitas Jenderal Soedirman,p.498, dikutip juga Hardianto Djanggih and Kamri Ahmad, The Effentiviness of Indonesian National Police of Investigation Function in Banggai Regency Police (Investigation Case Year 20082016, Jurnal Dinamika Hukum, Volume 17, Nomor 2, 2017, hlm.152 
mereka menyediakan sarana tempat persetubuhan.Prostitusi merupakan permasalahan yang sangat kompleks karena menyangkut berbagai aspek kehidupan masyarakat.

Kegiatan prostitusi menyangkut aspek sosial, gender, hukum, kesehatan, moral dan etika, agama, pendidikan, psikologis, ekonomi dan industrialisasi, dan juga masalah politik. ${ }^{3}$ Pasal 296 yang isinya yaitu:"Barang siapa dengan sengaja menyebabkan atau memudahkan perbuatan cabul oleh orang lain dengan orang lain, dan menjadikannya sebagai pencarian atau kebiasaan, diancam dengan pidana penjara paling lama satu tahun empat bulan atau pidana denda paling banyak lima belas ribu rupiah".

Dalam pasal 296 KUHP tersebut diatas adalah terkhusus pada para pelaku bisnis prostitusi terselubung yaitu panti pijat. yang mana diketahui bahwa panti pijat merupakan "surga prostitusi tersembunyi".Praktek prostitusi berkedok bisnis panti pijat mulai marak di Kota Makassar. Pemiliki bisnis esek-esek ini atau "pemuas nafsu sesaat" mengemas bisnisnya secara menarik artinya tidak dilakukan secara transparan. Tujuannya agar menjadi dagangan yang tidak lagi tabu dipandang, baik oleh masyarakat umum yang tak lagi berlabel lokalisasi, para pengusaha bisnis nikmat sesaat itu menyajikan tema baru dalam label usahanya. Padahal pada ujung-ujungnya sama, yakni praktik jasa pemuas nafsu syahwat.Fenomena prostitusi di Kota Makassar ini menjadi bukti bahwa adanya kesenjangan antara Undang-Undang dan penerapannya. Berdasarkan uraian di atas, maka masalah pokokpada penelitian ini adalah "Efektivitas KUHP terhadap tindak pidana prostitusi berkedok bisnis panti pijat di Kota Makassar.

\section{METODE PENELITIAN}

3 Arya Mahardika Pradana,Tinjauan Hukum Pidana Terhadap Prostitusi dan Pertanggungjawaban Pidana Para Pihak Yang Terlibat Dalam Prostitusi, dalam Jurnal Hukum dan Pembangunan Vol.45 No.2 April-Juni, 2015, hlm.276 
Tipe pada penelitian ini adalah kualitatif dengan pendekatan yuridis empiris. Penelitian ini akan berlangsung di beberapa panti pijat, dan Polrastabes di Kota Makassar. Populasi penelitian ini tertuju kepada pemilik panti pijat, karyawan (terapis), kepolisian, dan masyarakat (konsumen). Pengambilan sampel dilakukan dengan bentuk Purposive Sampling. Data pimer dianalisis berdasarkan deskriptif kualitatif dan data sekunder dianalisis berdasarkan deskriptif kuantitatif dalam bentuk tabulasi frekuensi dan distribusi presentase dengan rumus:

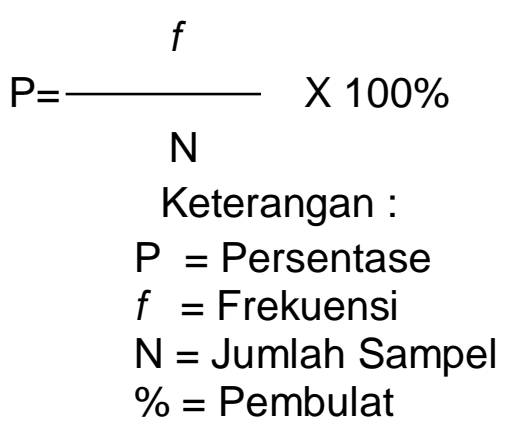

HASIL PENELITIAN

\section{Efektivitas KUHP terhadap Tindak Pidana Prostitusi Berkedok Bisnis Panti Pijat di Kota Makassar.}

Dalam konteks aturan hukum, tentang prostitusi telah diatur oleh hukum pidana yaitu dalam Kitab Undang-Undang Hukum Pidana (KUHP) pada Pasal 259 KUHP dan Pasal 506 KUHP. ${ }^{4}$ Keberadaan Pasal 295 dan 506 belum dapat mengakomodir penjatuhan pidana terhadap si pengguna bila dilihat dari unsur-unsur Pasal tersebut, yaitu terdapat unsur obyektif mengenai perbuatannya yang menyebabkan dilakukannya perbuatan prostitusi dan mempermudah terjadinya perbuatan prostitusi. ${ }^{5}$ Sesuai dengan letaknya didalam rumusan ketentuan pidana yang diatur dalam Pasal 296 KUHP, kesengajaan pelaku itu harus ditunjukan pada perbuatan-perbuatan memudahkan dilakukannya tindakan-tindakan

4 Mesites Yeremia Simangunsong. A.A Gede Agung Dharma Kusuma, Analisis Yuridis Mengenai Pertanggungjawaban Pidana Pengguna Jasa Prostitusi Dalam Perspektif KUHP, dalam Jurnal Kertha Wicara Vol.3 No.3 Juli, 2014, hlm.3

5 Ibid., 
melanggar kesusilaan oleh orang lain dengan pihak ketiga, dan membuat kesengajaan tersebut sebagai mata pencaharian atau sebagai kebiasaan, harus dipandang sebagai perbuatan memudahkan dilakukannya suatu tindakan melanggar kesusilaan yakni perbuatan menyewakan kamar untuk memberikan kesempatan kepada orang lain melakukan suatu tindakan melanggar kesusilaan dengan orang ketiga.Pasal 506 KUHP, barangsiapa menarik keuntungan dari perbuatan cabul seorang wanita dan menjadikan sebagai pencarian diancam dengan pidana kurungan paling lama satu tahun. ${ }^{6}$ Bertolak dari berbagai tuntutan normatif tersebut di atas, pemahaman terhadap unsur-unsur tindak pidana merupakan kebutuhan yang sangat mendasar berkaitan dengan penerapan hukum pidana materiil.

Berdasarkan observasi lapangan, terdapat dua jenis tipe panti pijat yang ada di kota makassar, yaitu panti pijat tradisional dan panti pijat plusplus yang berkedok panti pijat refleksi, sauna, dan spa. Untuk panti pijat tradisional biasanya menggunakan istilah pijat refleksi untuk menutupi layanan plus-plusnya. Untuk kalangan menengah keatas biasanya panti pijat plus-plus berkedok sebagai sauna dan spa karena layanan tersebut terbilang rapi dan jarang digrebek polisi.

Keberadaan panti pijat di Kota Makassar yang menyediakan jasa pijat plus-plus yang diduga adanya pelanggaran terhadap ketentuan Pasal 296 KUHP, maka tempat ini merupakan media baru bagi para pelaku seks terselubung dan tempat pelacuran, dan tanpa disadari ini semakin berkembang dari daya minat pelakunya, dan lama kelamaan dapat merusak moral generasi muda.Oleh sebab itu untuk mengetahui apakah peraturan tersebut telah efektif maka diperlukan faktor pengukur efektivitas dan penegakan suatu peraturan yang diantaranya Menurut teori hukum dari Soejono Soekanto dalam penegakan hukum terdapat faktor-

6 Melinda Novi Sari, Kebijkan Hukum Pidana Dalam Penanggulangan Tindak Pidana Prostitusi Melalui Media Online, dalam Jurnal Mahupiki Vol.1 No.1, 2014, hlm.4 
faktor yang mempengaruhi berhasil/ tidaknya penegakan hukum Itu sendiri yaitu:

1. Faktor hukum yang ditegakkan itu sendiri.

2. Faktor Aparat Penegak Hukum, yaitu aparatur penegak hukumnya.

3. Faktor masyarakat dimana hukum itu berada.

4. Faktor kebudayaan. ${ }^{7}$

Berkaitan teori/konsep hukum diatas, dalam penelitian ini bermaksud ingin mengkaji tentang teori hukum tersebut dengan keadaan empiris yang ada dimasyarakat. Peneliti menilai faktor aparat dan faktor masyarakat sangat berperan dalam mempengaruhi sulitnya penegakan hukum terkait khususnya menyangkut praktek Prostitusi. Adapun alasannya adalah; bila dilihat dari faktor hukum dan faktor kebudayaan sebagimana teori hukum tersebut, dari sudut pandang hukum/faktor Hukum, kepastian akan adanya hukum positif yang mengatur tentang praktek prostitusi dan sanksi pidananya telah jelas dan tegas sebagai mana tercantum dalam pasal Pasal 506 KUHP,sehingga seharusnya faktor hukum tidak dapat dijadikan sebagai alasan yang dapat menghambat penindakan terhadap praktek prostitusi tersebut. sedangkan dari sudut pandang faktor kebudayaan, budaya dan norma masyarakat Indonesia pada umumnya tidak ada yang menghalalkan terjadinya praktek prostitusi tersebut, sehingga faktor kebudayaan tidak dapat dijadikan sebagai argumen sebagai faktor yang mempengaruhi sulitnya penegakan hukum khususnya menyangkut praktek Prostitusi.

Pelacuran bila kita lihat dalam kitab undang-undang Hukum Pidana (KUHP) maka tidak ada satu pasalpun yang mengatur secara khusus, sehingga secara kriminologis sulit untuk mengatakan bahwa pelacuran itu

7 Soerjono Soekanto, Pengantar Penelitian Hukum, UI-Press, 2007, Jakarta. 
sebagai suatu kejahatan, sebab tidak menimbulkan korban. begitupula apabila dilhat delik-delik kesusilaan dalam kitab Undang-Undang Hukum Pidana ( Pasal 281 sampai pasal 303 ) khususnya pasal 296 dan pasal 506 Kitab Undang-Undang Hukum Pidana (KUHP) tidak ditunjukan pada Wanita Tuna Susila. melainkan ditujukan kepada pemilik rumah-rumah bordil yaitu para germo/muckari dan para calo. para germo dan calo dapat dihukum pidana bila karena perbuatan mereka sudah memenuh unsurunsur pasal 296 yang berbunyi "Barang siapa dengan sengaja menghubungkan atau memudahkan perbuatan cabul oleh orang lain, dan menjadikanya sebagai pencrian atau kebiasaan diancam dengan pidana penjara paling lama satu tahun empat bulan".Ini berarti bahwa palacuran apakah dia laki-laki atau perempuan bukan seorang penjahat dalam kualifikasi yuridis. akan tetapi hal ini bertentangan dengan sosiologi dari kejahatan (Sociological Difinition of crime) yakni, apa yang disebut dengan perbuatan jahat menurut norma-norrma sosial yang masih hidup dalam masyarakat, maka yang tidak dicantumkannya perbuatan melacur dalam Kitab Undang-Undang Hukum Pidana (KUHP), pihak kepolisian sering menemukan kesulitan dalam menghadapi persoalan Wanita Tuna Susila. melihat ayat demi ayat ini, maka menjadi jelas bahwa untuk Wanita Tuna Susila atau pelacuran dapat ditetapkan pasal 55 Jo pasal 296 Kitab Undang-Undang Hukum Pidana ( KUHP), yaitu dilarang dan diancam oleh Undang-Undang (Pasal $296 \mathrm{KUHP}$ ) sebagai orang yang turut serata melakukan perbuatan (Medepleger) atau membujuk melakukan perbuatan ( uitlokker) atau kebiasaan.

Menerapkan Pasal 296 Kitab Undang-Undang hukum Pidana ( KUHP ) melalui pasal 55 yang disebutkan diatas tidak tepat, karena pasal 296 hanya ditujukan kepada para germo saja, dengan tujuan untuk meberantas rumah-rumah bordil atau tempat-tempat pelacuran. dalam kenyataanya bahwa para pelacur bukan pemilik rumah-rumah bordil. melihat pasal 296, 297, 506 yang dapat dijumpai dalam Kitab UndangUndang Hukum Pidana ( KUHP ), yang berhubunan dengan prostitusi. 
ternyata mengenai si pelacur itu sendiri tidak tegas dinyatakan dalam hukum pidana. sedangkan sebagaimana halnya dengan wanita pelacur, tamu yang mendatang Wanita Tuna Susila belum juga diatur secara tegas dalam kitab undang-undang hukum pidana (KUHP). melihat delik delik kesusilaan yang diatur dalam kitab undang-undang hukum pidana (KUHP), yakni pasal 281 sampai pasal 303, amat sulit diterapkan pada wanita pelacur dan tamu yang datang mengunjunginya. bila hal tersebut akan dikenakan pada mereka, tentunya dalam kasus yang sangat khusus. Dari hasil penyebaran kuesioner yang dilakukan peneliti terhadap beberapa responden tentang "Bagaimanakah Efektivitas Penerapan Pasal 296 KUHP Terhadap Tindak Pidana Prostitusi Berkedok bisnis Panti Pijat di Kota Makassar" dapat dilihat pada tabel berikut :

Tabel 1. Penerapan Pasal 296 Terhadap Tindak Pidana Prostitusi Berkedok Bisnis Panti Pijat di Kota Makassar

\begin{tabular}{|c|l|c|c|}
\hline No. & \multicolumn{1}{|c|}{ Kategori Jawaban } & Frekuensi & Persentase \\
\hline & & & \\
1. & Efektif & 38 & $38 \%$ \\
2. & Tidak Efektif & 62 & $62 \%$ \\
\hline \multicolumn{2}{|c|}{ Jumlah } & 100 & $100 \%$ \\
\hline
\end{tabular}

Sumber data: diolah berdasarkan hasil kuesioner, 2017

Dari data pada tabel diatas menjelaskan bahwa Efektivitas Pasal 296 KUHP Terhadap Tindak Pidana Prostitusi Berkedok bisnis Panti Pijat di Kota Makassar tidak efektif, terbukti dari jawaban responden yang menjawab efektif hanya sebanyak 38 orang responden dan yang menjawab tidak efektif sebanyak 62 orang responden. Hal ini pun diperkuat dengan wawancara yang dilakukan peneliti terhadap beberapa aparat penegak hukum di Polrestabes Makassar, menyatakan bahwa memang sulit untuk mengungkap bisnis haram tersebut karena pada Pasal yang terdapat pada KUHP tidak mengatur secara tegas dan detail soal prostitusi yang terjadi pada bisnis panti pijat ini, dan juga pasal 
tersebut bersifat delik aduan, jadi kalau tidak ada pihak yang mengadu maka kami pun tidak akan melakukan penyelidikan.Seakan menjadi kebenaran universal dalam menafsirkan pasal-pasal mengenai delik susila, para penegak hukum memberi pendapat sama tentang penerapan hukum. Jika pasal-pasal tersebut di atas diterapkan secara sembarangan tentu pihak Kepolisian sendiri yang menanggung malu, atau bahkan bisa dituntut misalnya karena langsung menangkap, menahan (pra peradilan) tanpa memperhatikan ketentuan hukum baik materil (pasal-pasal terkait) maupun formil (prosedur), oleh karena itu pihak kepolisian selalu menerapkan sikap cermat penuh kehati-hatian dalam mengambil tindakan represif terhadap praktek-praktek prostitusi.

Adapun daftar nama-nama panti pijat di Kota Makassar yang menjadi objek penelitian ini adalah sebagai berikut:

1. Comfort Spa, Jl. Boulevard

2. Metro Spa, Jl. Pengayoman

3. Delta Spa Jl Andi Pangeran Pettarani

Panti pijat ini beroperasi sekitar antara pukul 13.00 siang sampai 23.00 malam. Di setiap panti pijat tersebut hanya bertuliskan spa. Di dalam panti pijat tersebut terpampang pengumuman larangan berbuat asusila antara pelanggan dan terapisnya.Berdasarkan hasil wawancara penulis pada salah satu pelanggan panti pijat Metro Spa, seringkali terapis menawarkan langsung jasa sex oral ataupun hand job yang harganya bisa di negoisasikan antara pelanggan dan terapis. Tidak ada perbedaan yang signifikan dari ketiga panti pijat tersebut, hanyatarif di setiap panti pijat cukup beragam, di Metro Spa tarifnya mencapai Rp 350.000 + spa dan sauna tidak termasuk layanan plus plus, akan tetapi bisa dinegosiasikan dengan terapis. Camfort Spa tarifnya mencapai Rp $400.000+$ spa + handjob, dan layanan plus plus dapat dinegosiasikan dengan terapis dan Delta Spa tarifnya Rp 600.000 + spa + handjob, dan untuk layanan plus plus yang lain, panti pijat ini tidak menerima. 
Setiap panti pijat biasanya hanya memasang nomor untuk para terapis, hal ini pun ditengarai sebagai salah satu cara untuk mensiasati Pasal 282 KUHP. Dari hasil wawancara yang dilakukan oleh salah satu terapis(Novie) di panti pijat tersebut mengatakan bahwa tempat ini begitu safety karena tempat ini pun sudah mendapat beckingan dari salah satu aparat penegak hukum. Walaupun bayaran yang mereka peroleh dari perusahaan sangat sedikit, dan hanya berharap dari para tamu yang masuk tetapi mereka merasa aman untuk menjajakan dirinya ditempat ini.Adapun perbuatan yang mereka lakukan didalam, hanya terapis dan tamu yang mengetahuinya walaupun pada setiap kamar terdapat tulisan "dilarang berbuat asusila".

Sejauh ini, pemerintah kota makassar belum mengambil sikap untuk mengatasi praktik terlarang tersebut. Salah satu alasan mengapa pemerintah daerah dan pihak kepolisian seolah tutup mata dengan adanya tempat-tempat prostitusi terselubung seperti panti pijat adalah pendapatan asli daerah (PAD) dari pajak panti pijat itu sangat besar. Pada Perda Kota Makassar Nomor 2 Tahun 2012 atas perubahan Perda Kota Makassar Nomor 3 Tahun 2010 tentang Pajak Daerah Kota Makassar pada Pasal 1 huruf j, menyatakan bahwa pajak panti pijat, mandi uap/spa, sebesar 50\% (lima puluh persen), hal ini pun menjadi alasan pemerintah kota untuk tetap memberikan izin bagi siapa saja pelaku usaha yang membuka bisnis panti pijat, mandi uap/spa.

Dalam Usaha penanggulangan prostitusi memang dirasa sangat sulit dan sukar sebab harus melalui beberapa proses dan waktu yang panjang serta dengan biaya yang cukup besar. Usaha yang dilakukan untuk penanggulangan tersebut biasanya dengan tindakan preventif dan represif.

Usaha yang bersifat preventif biasanya diwujudkan dalam bentuk dan tindakan-tindakan pencegahan yang bertujuan untuk mencegah timbulnya praktik prostitusi. Tindakan-tindakan tersebut seperti: 
1. Adanya ketegasan dan penyempurnaan atas undang-undang ataupun peraturan yang mengatur dan melarang masalah penyelenggaraan praktik prostitusi;

2. Intensifikasi pendidikan keagamaan dan kerohanian untuk meningkatkan keimanan terhadap nilai-nilai agama dan moral;

3. Penjaringan pelaku-pelaku prostitusi untuk diserahkan kepada dinas sosial dan dilakukan rehabilitasi serta resosialisasi. Rehabilitasi dilakukan dengan memberikan pendidikan keterampilan agar sekembalinya kemasyarakat dapat memulai pekerjaan baru dengan keterampilan yang telah diberikan. Resosialisasi merupakan usaha untuk memberikan rasa percaya diri kepada pelaku prostitusi ketika harus kembali kemasyarakat. Selain itu, mereka juga diberi pengertian bahwa ketika merka telah kembali kemasyarakat, posisi mereka adalah untuk memperbaiki diri dan berbaur bersama masyarakat sehingga tidak kembali pada pekerjaan sebelumnya.

4. Masyarakat, khususnya orang tua dan tokoh masyarakat. Masyarakat sebagai orang yang berada dekat dengan praktikpraktik prostitusi sudah sepantasnya menjadi hal pertama yang melakukan penanggulangan agar dampak yang ditimbulkan tidak membahayakan kondisi sosial. Tokoh masyarakat senantiasa melakukan kontrol terhadap aktivitas praktik prostitusi terselubung dilingkungan sekitarnya. Dengan melakukan kontrol, masyarakat dapat melayangkan teguran sekiranya praktik tersebut sudah menimbulkan keresahan warga dan mulai mencemarkan nama baik lingkungan tempat tinggal di daerah tersebut.

5. Pembentukan tim koordinasi dari instansi terkait yang bekerja sama dengan masyarakat lokal dalam rangka penanggulangan praktik prostitusi, dalam hal ini pemerintah kota Makassar, pihak kepolisian dan para pengusaha hiburan malam. 
6. Melakukan patroli rutin. Patroli yang dimaksud disini adalah pemantauan secara langsung terhadap obyek-obyek yang diduga rawan kejahatan, dalam hal ini ditengarai adanya praktek prostitusi. Patroli biasanya dilakukan secara rutin dan berkala, terutama hari-hari yang potensi dilakukannya prostitusi seperti sabtu malam ataupun minggu malam, namun dalam hal ini biasanya dilakukan bersamaan dengan operasi narkoba. Dalam patroli ini pihak kepolisian menugaskan anggota satuan reskrim dengan menyamar sebagai pengunjung, sangat jarang bahkan hampir tidak pernah memakai seragam kepolisian. Oleh karena itu yang bisa dilakukan oleh pihak kepolisian hanya melakukan patroli secara sidak, sebagai upaya penanggulangan semata. Dan biasanya pihak pengelola lebih lihai dalam menyiasati kehadiran petugas. Jika ada laporan, biasanya pihak Kepolisian segera menindaklanjuti dengan penugasan terhadap anggota untuk melakukan pengecekan dan permintaan keterangan pihak hotel, tapi selama ini belum pernah terbukti setiap laporan itu ternyata hanya dugaan-dugaan saja, sebab ternyata setelah diadakan investigasi tidak terbukti adanya prostitusi.

Selain tindakan preventif dalam penanggulangan prostitusi juga dilakukan tindakan represif dengan tujuan menekan, menghapus, dan menindas serta usaha penyembuhan terhadap para pelaku praktik prostitusi untuk dibawa ke jalan yang benar. Usaha tersebut antara lain:

1. Penutupan atau pencabutan izin usaha bagi usaha panti pijat yang melakukan prostitusi terselubung, dan memberikan sanksi administratif maupun sanksi pidana sesuai yang diatur dalam Perda No.5 Tahun 2011 dan KUHP.

2. Melakukan kontrol dan pengawasan yang ketat terhadap para wanita tuna susila yang ada di panti-panti pijat, sehingga apabila ada wanita tuna susila yang terinfeksi penyakit maka segera 
diberikan pengobatan agar tidak terjadinya penularan penyakit terhadap para pengguna jasa prostitusi;

3. Mengadakan rehabilitasi dan resosialiasi terhadap para wanita tuna susila agar mereka dapat dikembalikan sebagai anggota masyarakat yang susila. Rehabilitasi dan resosialisai dilakukan dengan cara pemberian pendidikan moral dan agama, latihan kerja, pembinaan sesuai minat dan bakat masing-masing, pendidikan keterampilan dengan tujuan agar mereka menjadi manusia yang kreatif dan produktif;

4. Menyediakan lapangan kerja baru bagi para wanita tuna susila yang bersedia meninggalkan profesinya sebagai pelacur dan yang mau memulai hidup susila;

5. Mengadakan pendekatan kepada pihak keluarga dan masyarakat asal wanita tuna susila agar mereka dapat menerima kembali mantan wanita tuna susila untuk mengawali hidup baru;

6. Mencarikan pasangan hidup yang permanen (suami) bagi wanita tuna susila untuk membawa mengawali hidup baru;

7. Melakukan tindakan persuasif. Tindakan yang dimaksud adalah meminta keterangan para pengelola hotel atas adanya laporan atau pengaduan serta indikasi adanya praktek prostitusi. Langkah ini dilakukan dengan penuh hati-hati. Tindakan tersebut belum bisa dikategorikan penyelidikan ataupun penyidikan.

\section{KESIMPULAN}

Dari uraian tersebut, dengan ini peneliti kemukakan beberapa hal sebagai kesimpulan, sebagai berikut: Efektifitas aturan KUHP terhadap tindak pidana prostitusi berkedok bisnis panti pijat di Kota Makassar tidak efektif, karena masih adanya beberapa panti pijat yang beroperasi secara terselubung dan tidak sesuai dengan izin usaha sebagaimana mestinya sehingga dengan mudah menyebabkan perbuatan cabul oleh orang lain 
dengan orang lain.Upaya-upaya yang dapat dilakukan dalam mencegah terjadinya Prostitusi terselubung di panti pijat yaitu:Upaya Pencegahan (Preventif) dan Upaya Penanggulangan (Represif).

\section{SARAN}

Seharusnya pemerintah pusat melakukan revisi KUHP untuk mengatur secara tegas terkait kejahatan kesusilaan ataupun kejahatan prostitusi terselubung, sehingga pihak kepolisian dapat bertindak semaksimal mungkin dengan dukungan peraturan yang mempunyai kepastian hukum.Pemerintah Kota Makassar perlu melakukan peninjauan kembali terhadap izin usaha panti pijat dan melakukan verifikasi langsung kelapangan serta berani melakukan tindakan berupa sanksi administratif maupun sanksi pidana sebagaimana di atur dalam peraturan perundangundangan.

\section{REFERENSI}

\section{Buku:}

Soerjono Soekanto, 2007,Pengantar Penelitian Hukum, UI-Press, Jakarta.

\section{Jurnal:}

Arya Mahardika Pradana, Tinjauan Hukum Pidana Terhadap Prostitusi dan Pertanggungjawaban Pidana Para Pihak Yang Terlibat Dalam Prostitusi, dalam Jurnal Hukum dan Pembangunan Vol.45 No.2 April-Juni, 2015.

Dayanto, "Rekonstruksi Paradigma Pembagunan Negara Hukum Indonesia Berbasis Pancasila", Jurnal Dinamika Hukum, Vol. 13, No. 3, September 2013

Hardianto Djanggih and Kamri Ahmad, The Effentiviness of Indonesian National Police of Investigation Function in Banggai Regency Police (Investigation Case Year 2008-2016, Jurnal Dinamika Hukum, Volume 17, Nomor 2, 2017 
Melinda Novi Sari, Kebijkan Hukum Pidana Dalam Penanggulangan Tindak Pidana Prostitusi Melalui Media Online, dalam Jurnal Mahupiki Vol.1 No.1, 2014.

Mesites Yeremia Simangunsong. A.A Gede Agung Dharma Kusuma, Analisis Yuridis Mengenai Pertanggungjawaban Pidana Pengguna Jasa Prostitusi Dalam Perspektif KUHP, dalam Jurnal Kertha Wicara Vol.3 No.3 Juli, 2014.

Muntoha, Demokrasi dan Negara Hukum, dalam Jurnal Hukum lus Quia lustum Vol.16 No.3 Juli, 2009.

Peurndang-Undangan

Undang-Undang Dasar Negara Republik Indonesia Tahun 1945

Undang-Undang Nomor 1 Tahun 1946 Tentang Kitab Undang-Undang Hukum Pidana 